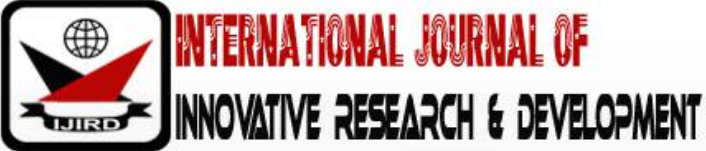

ISSN 2278-0211 (Online)

\section{The Principle of Good Governance: A Study of the Implementation of 'Algemene Beginselen Van Behoorlijk Bestuur' in the Legal System in Indonesia}

\begin{tabular}{c}
\hline La Ode Husen \\
Lecturer, Department of Law, Universitas Muslim Indonesia, Indonesia \\
Mukmin Muhammad \\
Student of Doctoral Program, Department of Law, Universitas Muslim Indonesia, Indonesia \\
Hamza Baharuddin \\
Lecturer, Department of law of Universitas Muslim Indonesia, Indonesia \\
Nurul Qamar \\
Lecturer, Department of law, Universitas Muslim Indonesia, Indonesia \\
\hline
\end{tabular}

\begin{abstract}
:
This research article aims to find out the Principles of Good Governance in a study of the implementation of 'Algemene Beginselen van Behoorlijk Bestuur' in the legal system in Indonesia relating to General Principles of Decent Governance (1) which are basically rules public law that must be followed by the court in implementing positive law. These, principles constitute a special category of. This is a special category of general legal principles and is considered a formal source of law in administrative law where the principle of good governance is a priority. The method used by researchers is the Research method This is carried out by conducting a literature study, a literature study is an activity to gather information that is relevant to the topic or problem that is the object of research. Such information can be obtained from books, thesis scientific works, dissertations, encyclopedias, the internet, and other sources. The results showed that in carrying out all its affairs, that is any matter in the field of State Administration, the State Administration Officer (TUN) must be guided by ABBB. Based on legal doctrine, ABBB basically has two principles, the first is a procedural principle, and the second is a substantial principle.
\end{abstract}

Keywords: Government, decent, country, principle

\section{Introduction}

There are so many kinds of deviations committed by the government, such as onrechtmatige overheidsdaad, detournement de pouvoir, and willekeur. Onrechtmatige overheidsdaad is an unlawful act carried out by the government, detournement de pouvoir is a form of abuse of power committed by the government, and willekeur is a form of arbitrariness committed by the government. Therefore, it is not surprising, if in the Netherlands and several other European countries guaranteeing and recognizing the right to apply the principles of Decent governance, as part of fundamental rights.1

In essence, the development of the concept of 'alignment beginselen van behoorlijk bestuur' (ABBB) itself can actually be pulled back to the beginning of the last century. These principles have begun to develop in the Dutch legal literature since the early 19th century. At that time, various jurisprudence began to emerge in connection with the means of supervising judges on the validity of government actions. 2

However, since the 1950s the government has begun to develop a clearer policy regarding general principles of good governance. This was done because the Dutch government felt it was necessary to develop guidelines for the administration of government in the context of exercising its authority, so that later there would not be any name of a conflict of interest between the government and its people. For this reason, the Dutch government subsequently formed an expert commission which in 1946-1950 was led by de Monchy. As for in 1946, one of the tasks given to the commission led by de Monchy was to think about and research about alternatives to 'rechtsbescherming verhoogde', namely to increase legal protection given to the public for deviant actions in relation to the State Administration. Based on his thoughts and

1 Lihat Jens-Peter Bonde, The European Union Constitution, Lihat PART II CHARTER OF FUNDAMENTAL RIGHTS OF THE EUROPEAN UNION, Title III. Equality, Art. II-103, the right to get protection from maladministration, Art. II-107, impartial tribunal, Art. II-108, the right to defence, Art. II - 109, legality and proportionality principles, The Constitution-The Reader-Friendly Edition. http://en.euabc.com/upload/rfConstitution en.pdf. Ibid 
research on the 'rechtsbescherming verhoogde', the de Monchy Commission in 1950 reported the results of this research in the form of 'beginner van behoorlijk bestuur', which contains the general principles of good governance as to what should be implemented.

As for 1986, Indonesia actually passed Law Number 5 of 1986 concerning State Administrative Court. Subsequently, the Law was amended through Law No. 9 of 2004 concerning Amendments to Law Number 5 of 1986 concerning State Administrative Court. Furthermore, in this Law, the development has undergone a change, namely as a basis for the AUPB principle lawsuit, inclusion in Article 53 paragraph (2).

This is a leap of progress that cannot be separated from the contribution of Prof.'s thoughts. Paulus Effendi Lotulung (Supreme Court) who at the Working Committee Meeting (Panja) on 30 January 2004 in the DPR proposed the inclusion of the AUPB principle. This proposal was supported by the Government and the Factions in the DPR.

This AAUPB was then legally regulated in the 2004 PTUN Law Article 53 Paragraph (1) and Paragraph (2), as well as in the Elucidation of Article 53 Paragraph (1) and Paragraph (2). As for Article 53 Paragraph (1), in fact this Article emphasizes the legal rights of individuals and legal entities through the TUN Justice, where if the rights of individuals and legal entities are proven to be impaired by the organizer of the State. Furthermore, in article 53 paragraph (2), in fact this article emphasizes that in addition to violations of the written law, other violations that can be used as a basis for filing a lawsuit against state administrators are violations of AAUPB. In the 1990s, UNDP introduced a principle called with good governance. Law No. 28 of 1999 concerning State Administration that is clean and free of Collusion of Corruption and Nepotism (KKN) begins with a draft law proposed by the government. This draft law from the very beginning had carried the, principle as its main foundation, although at that time the term used was the General Principles of State Administration (AUPN) and the General Principles of Good State Governance (AUPNB), and not AUPB. As for article 3 of the Act a quo contains seven important principles, the first principle is the Principle of Legal Certainty, the second principle is the Principle of Organizing the State, the third principle is the Principle of Public Interest, the fourth principle is the Principle of Openness, the fifth principle is the Principle of Proportionality, the Sixth Principle is The Professionalism Principle, and the seventh Principle, the Accountability Principle. Then regarding the spirit of anti-Corruption, Collusion, and Nepotism, or commonly referred to as Collusion, corruption and Nepotism, contained in the 1999 Not Collusion, corruption and Nepotism Law, which is a spirit in reforming and eradicating Collusion, corruption and Nepotism(KKN), which is a concrete manifestation as part of the follow up to the Decree of the Republic of Indonesia Number XII / MPR / 1998 concerning the Organization of a State that is Clean and Free of Corruption, Collusion and Nepotism. In the Decree of the Republic of Indonesia MPR, there is one of the main provisions which is quite crucial, which encourages the creation of good governance (goor governnace), as stated in letter c, namely: 'To carry out its functions and duties the organizer must be honest, fair, open, and trusted, and able to free themselves from the practices of corruption, collusion, and nepotism :

\section{Research Method}

This research was conducted by conducting a literature study, literature study is an activity to collect information relevant to the topic or problem that is the object of research. Such information can be obtained from books, thesis scientific works, dissertations, encyclopedias, the internet, and other sources. By conducting a literature study, researchers can utilize all information and thoughts relevant to their research that discusses 'Principles of Governance' Good Governance a study of the implementation of 'Algemene Beginselen van Behoorlijk Bestuur' in the legal system in Indonesia.

\section{Discussion}

'Algemene Beginselen van Behoorlijk Bestuur'. General Principles of Decent Governance General Principles of Decent Government (,) are translations of 'Algemene Beginselen van Behoorlijk Bestuur' (ABBB), a term in Dutch. In England, this principle is known as 'The Principal of Natural Justice' or 'The General Principles of Good Administration', while in France it is termed 'Les Principaux Generaux du Droit Coutumier Publique' and in Belgium it is called 'Algemene Rechtsbeginselen', and in Belgium Germany is called 'Allgemeine Grundsätze der Ordnungsgemäßen Verwaltung'.3

In carrying out all its affairs, that is any matter in the field of State Administration, the State Administration Officer (TUN) must be guided by ABBB. Based on legal doctrine, ABBB basically has two principles, the first is a procedural principle, and the second is a substantial principle. What is meant by procedural principles are the principles adopted in relation to the policy making process, for example the government administrator is obliged to be able to act impartially in the process of policy making, recognizing the right to defend himself, and policy makers have an obligation to be able to give reasons clearly. Whereas what is meant by a substantial principle are the principles adopted related to the material or content of a policy. In this principle, it is explained that the material or content of a policy made, which of course is in the public interest, including must take into account the principle of equality, the principle of legal certainty, prohibition of abuse of authority (prohibition of 'machtsafwending') ), duty to care (duty of care), and principles based on fairness (principle of reasonableness).

State administration at that time. After the General Principles of Decent Government began to be regulated as one of the basic tests in the 'Wet Arbo', similar construction began to be applied to various other laws which were also intended to protect the rights of citizens. During this period, legal literature emerged about the, including the decisions of

Von Bernd Grzeszick, Erlangen, 2006. Das Grundrecht auf eine gute Verwaltung - Strukturen und Perspektiven des Charta-Grundrechts auf eine gute Verwaltung, Europarecht, In Verbindung mit der Wissenschaftlichen Gesellschaft für Europarecht

http://www.europarecht.nomos.de/fileadmin/eur/doc/Aufsatz_EUR_06_02.pdf. 
Hoge Raad which declared the illegality of government actions, because they were considered contrary to the principles of Decent governance.4

General Principles of Good Governance basically has two functions. Function the first is as a tool used by judges in testing and or assessing the validity of an administrative action when the existing legal provisions and / or applicable decisions do not have sufficient clarity in providing a regulation. Next the second function is as a tool used to control in the framework of its efforts to prevent an administrative action that is considered to cause arbitrariness towards the people. Then in further developments, the AAUPB has been recognized and accepted as a legal norm by government officials to be used as a basis for carrying out all forms of authority, and has also been used as a basis for deciding a case by a judge.

The history of the development of General Principles of Good Governance in Indonesia basically can be seen in the applicable laws and regulations.

The history of this development, in addition to being seen in various applicable laws and regulations, as for the practice of its implementation, can be seen in the form of court decisions or jurisprudence and doctrine. The development of the General Principles of Good Governance principle, from the principle of unwritten transitions to written legal standards, is indeed rather slow to occur. This is because General Principles of Good Governance has not been explicitly regulated in the 1986 PTUN Law, which is where we can more clearly see Article 53 (2) of this law, where in this article it is not explicitly stated that General Principles of Good Governance is used as a basis for submitting TUN decision. At the time of the formation of Law Number 5 of 1986 Concerning State Administrative Court, the minutes of the Law stated that the ABRI Faction had proposed the AUPB concept. However, the proposal was rejected by the Minister of Justice, Ismail Saleh, on the grounds that the practice is contrary to the principles of governance in the state administration and in the State Administrative Law in (TUN) Indonesia, does not yet have the criteria 'alignment beginselen van behoorlijk bestuur' (general principles of government governance which is Decent), as is the case in the Netherlands and in Continental European countries.5

The above, also as stated by Adriaan Bedner, which is where he stated that in Indonesia in the early days of the establishment of the PTUN Law, in the debate that took place in the Government parliament finally jointly agreed that administrative justice would apply the principles Decent governance as applicable in the Netherlands (AROB). However, for political reasons, in the end this was not done.

Furthermore, after it was stated that the 1986 PTUN Law was effectively applied in all parts of Indonesia, namely as of January 14, 1991, the State Administrative Court had already handed down a decision, namely by stating that the TUN decision was null or void, because this was considered contrary to good governance (general principles of good governance).

In further developments, the regulation of the AUPB principle has found momentum that has further strengthened this principle, namely when in 2014 the Government Administration was passed by Law. At that time, namely when Law No. 30 of 2014 concerning Government Administration, also known as the 2014 AP Law is still a bill in the DPR, which is still in the process of discussion, the General Principles of Good Governance principle has become a mainstreaming issue in the discussion of the preparation of this bill. Prof. Eko Prasojo, who was then serving as Deputy Minister of the State Apparatus Empowerment and Bureaucratic Reform (WB Menpan RB), proposed for the inclusion of General Principles of Good Governance (AUPB) during a meeting on the discussion of Problem Inventory List (DIM) with the DPR ongoing. Furthermore, of the many types of General Principles of Good Governance proposed by the government, there is an additional proposal for one principle put forward by the Golkar Party (FPG) Faction, namely regarding the principle of good service. In addition to the principles proposed by the FPG as well as the principles proposed by the government, all the factions in the DPR at that time, were directly or indirectly aware that the Judge actually made a decision or a lawsuit by the Official or Government Agency, it was very possible that the principles that might be used as a basis for consideration. In other words, based on the proposal, this means that the meeting participants at that time expressed their agreement that there are still other principles outside the AUPB, as referred to in the 2014 AP Law, and this should also be applicable by As long as the judge is used as the basis for the assessment, the assessment will be contained in a court decision with permanent legal force. Other principles beyond the principles mentioned in Article 10 Paragraph (2) can be interpreted as additional General Principles of Good Governance adopted by judges from various applicable laws or regulations or from doctrines developed by experts in State Administrative Law6

The diversity of the use of the term 7 in Indonesia can be seen from the difference in the use of the term in various literatures and laws and regulations. There are at least four different terms, but are intended to have the same meaning as the General Principles of Decent Government(,)8, namely the term General Principles of Decent Governance9, General Principles of State Administration 10, General Principles of Decent State Government, The Principle of Organizing Local

van Wijk, Konijnenbelt, van Male, hlm. 271-272. Salah satu literatur yang cukup berpengaruh adalah I. Samkalden \& G.J. Wiarda, Algemene Beginselen van Behoorlijk BestUndang-Undangr, disampaikan pada rapat umum anggota 'Perkumpulan HukumAdministrasi', 30 Mei 1952

Risalah rapat pembahasan RUNDANG-UNDANGPTUN, Pembicaraan Tingkat II/Jawaban Pemerintah atas Pemandangan Umum Fraksi ABRI atas RUNDANG-UNDANGPTUN, Selasa, 20 Mei 1986, hlm. 148

$6 \quad$ Menurut penjelasan Pasal 10 ayat (2), bahwa yang dimaksud dengan 'asas-asas umum lainnya di luar AUPB' adalah asas umum pemerintahan yang baik yang bersumber dari putusan pengadilan Negeri yang tidak dibanding, atau Putusan Pengadilan Tinggi yang tidak dikasasi atau Putusan Mahkamah Agung

Lihat UNDANG-UNDANGAP, UNDANG - UNDANG PTUN, bandingkan dengan Pasal 3 UNDANG-UNDANGOmbudsman yang hanya menggunakan istilah 'asas'.

8 Jazim Hamidi, Penerapan Asas-Asas Umum Penyelenggaraan Pemerintahan yang Layak (AAUPL) di Lingkungan Peradilan Tata Usaha Negara, Bandung: Citra Aditya Bakti, 1999, hlm. 21

Ibid, UNDANG-UNDANGAP Tahun 2014

10 Ibid, UNDANG-UNDANGAP Anti KKN 
Government (APPD) 11, Principles of Good Governance, Principle of Providing Public Services 12, Principle of Organizing Policy and Management of the State Civil Apparatus7

The following table presents the various uses of the term contained in statutory regulations - The following table presents the diversity of uses of the term contained in statutory regulations and some literature written by State Administrative Law experts: 8

\begin{tabular}{|c|c|c|}
\hline TERM & law & EXPERT \\
\hline $\begin{array}{l}\text { General Principles } \\
\text { Good govemance } \\
\text { (AAUPB)/(AUPB) }\end{array}$ & $\begin{array}{l}\text { AP } 2014 \text { Law and Law } \\
2009 \text { Ombudsman } \\
\text { use the term } \\
\text { same, with one } \\
\text { the word "principle" }\end{array}$ & $\begin{array}{l}\text { Kuntjoro Purbopranoto, Indroharto, Amrah } \\
\text { Muslimin, M. Solly Lubis, Muchsan, } \\
\text { Paulus Effendi Lotulung, Moh. Mahfud } \\
\text { Md, SF. Marbun } 50\end{array}$ \\
\hline $\begin{array}{l}\text { General Principles } \\
\text { Implementation } \\
\text { Yang's govemment } \\
\text { Eligible (AAUPPL) }\end{array}$ & - & Jazim Hamidi \\
\hline $\begin{array}{l}\text { General Principles } \\
\text { State Administration } \\
\text { (AUPN) }\end{array}$ & $\begin{array}{l}\text { Law Number } 28 \text { Year } 1999 \text { conceming } \\
\text { State Administrators who are Clean and } \\
\text { Free of Comuption, Collusion and } \\
\text { Nepotism, }\end{array}$ & - \\
\hline $\begin{array}{l}\text { Implementation Principle } \\
\text { Local government } \\
\text { (APPD) }\end{array}$ & $\begin{array}{l}\text { laws of the republic indonesia } \\
\text { number } 23 \text { of } 2014 \\
\text { about } \\
\text { local govermment }\end{array}$ & - \\
\hline $\begin{array}{l}\text { Asas Penyelenggaraan } \\
\text { Kebijakan dan } \\
\text { Manajemen Aparatur } \\
\text { Sipil Negara }\end{array}$ & $\begin{array}{l}\text { laws of the republic indonesia number } 5 \text { of } \\
2014 \text { about country civil apparatus }\end{array}$ & - \\
\hline
\end{tabular}

Table 1: Glossary of Terms Used by Experts

Source:Https://Leip.Or.Id/Wp-Content/Uploads/2016/05/Penjelasan-Hukum-Asas-Asas-Umum-Pemerintahan-Yang-BaikHukum-Administrasi-Negara (Accessed Onjune 6, 2020)

Just as the terminology is different, so in interpreting or defining AUPB, experts also give different definitions. According to Indroharto, General Principles of Decent Government (,) (read: AUPB), is part of general legal principles that are specifically applicable and important for government legal actions. F.H. Van Der Burg and G.J.M. Cartigny more specifically provide a definition of, as 'unwritten legal principles that must be considered by a State administration body or official' in carrying out legal actions which will be assessed later by the Administrative Judge.13

Based on the general Principles of Decent Government understanding from several experts, Jazim Hamidi summarizes the elements that make up the general Principles of Decent Government definition, as follows:14

- General Principles of Decent Government, is the ethical values that live and develop in the legal administrative environment of the State;

- general Principles of Decent Government has a function as a guide for the Acting State Administration in carrying out its functions, namely for Administrative Judge.general Principles of Decent Government is a test tool used in evaluating an act that is a State Administration, (both tangible determination / beschikking), and for the plaintiff can be used as a plaintiff the basis for filing a lawsuit;

- Most general Principles of Decent Government are still abstract in nature, because they are unwritten principles, so this makes them more probable in social life;

- Some of the principles have changed into written legal principles and are contained in various positive legal regulations in force in Indonesia. However, its nature remains as a legal principle even though some of the principles have been changed to written legal rules.

- AAUPPLGeneral Principles of Decent Government has a function as a guide for the Acting State Administration in carrying out its functions, namely for Administrative Judge General Principles of Decent Government , is a test tool used in evaluating an act that is a State Administration, (both tangible determination / beschikking), and can be used as the basis of a claimant claimants for filing.

- Most of the General Principles of Decent Government are still abstract, because they are unwritten principles, so this makes it possible to be explored more deeply in social life.

Pasal 58 Undang-Undang Nomor 23 Tahun 2014 tentang pemerintah Daerah

Lihat UNDP Report

Olden Bidara, 'Asas-asas Umum Pemerintahan Yang Baik Dalam Teori dan Praktek Pemerintahan', dimuat dalam Paulus Effendi Lotulung (Ed.), Ibid. hlm. 80

14 Jazim Hamidi, Penerapan Asas-Asas Umum Penyelenggaraan Pemerintahan yang Layak (AAUPL) di Lingkungan Peradilan Tata Usaha Negara, Bandung: Citra Aditya Bakti, 1999, hlm. 24 
- Some of the principles have been changed into written legal rules and spread in various positive legal regulations that apply in Indonesia. However, its nature remains as a legal principle even though some of the principles have been transformed into written legal rules.

According to Indroharto, general Principles of Decent Government AUPB is very important in the study of State administration, due to: 15

- General Principles of Decent Government, is part of the applicable positive law;

- General Principles of Decent Government, is the norm for State administrative actions, in addition to written and unwritten legal norms;

- General Principles of Decent Government, can be used as a reason for filing a lawsuit, and finally the AUPB can be used as a 'test tool', by the administrative judge to assess whether or not a State Administration decision is invalid.

Indroharto also stated, General Principles of Decent Government, provided three aspects of legal discovery, including:

- In the field of interpretation and application of the provisions of the legislation;

- In the area of the formation of government regulations government organs are given freedom of wisdom by statutory regulations or there are no provisions that limit the freedom of policy to be carried out;

- At the time of exercising discretion.

Related to what was stated by Indroharto, Sjachran Basah stated:16

'Even though the State Administration actually has full discretion in determining policies, but its attitude and actions must still be accountable, both moral responsibility to Allah SWT, and legal responsibility by taking into account the applicable restrictions, namely the upper limit and the lower limit based on consideration of the 1945 Constitution as a benchmark. 'Although the State Administration has the freedom to determine policies, the attitude of its actions must be morally responsible to Allah SWT, and legally must pay attention to the upper and lower limits, taking into account the Republic of Indonesia Act 1945 as a benchmark. '

Philipus M. Hadjon states17, there is no specific list that states how many principles from the AUPB are definitively, because these principles are 'levende beginselen' which develop according to specific practices through the decisions of the Judiciary. Furthermore, from all of these principles, Indroharto groups them into more systematic ways as shown in the table below.18

\begin{tabular}{|c|c|c|c|c|c|}
\hline \multicolumn{2}{|r|}{$\begin{array}{l}\text { Principles - Formal } \\
\text { Principles Regarding } \\
\text { Decision Making }\end{array}$} & \multicolumn{2}{|c|}{$\begin{array}{l}\text { Principles - Formal } \\
\text { Principles Regarding } \\
\text { Decision Formulation }\end{array}$} & \multicolumn{2}{|r|}{$\begin{array}{l}\text { Material Principles Regarding the } \\
\text { Content of Decisions }\end{array}$} \\
\hline 1. & $\begin{array}{l}\text { Principle of Formal } \\
\text { Accuracy }\end{array}$ & 1. & $\begin{array}{c}\text { Principle of } \\
\text { Consideration } \\
\end{array}$ & 1. & $\begin{array}{l}\text { The principle of material is legal } \\
\text { certainty }\end{array}$ \\
\hline 2. & The Fair Play Principle & 2. & $\begin{array}{l}\text { Principle of Legal } \\
\text { Certainty }\end{array}$ & 2. & $\begin{array}{l}\text { Principle of Trust or Hope - } \\
\text { Expectations that have been raised }\end{array}$ \\
\hline 3. & Prohibition Principle & & Formal & & have been raised \\
\hline & detournament & & & 3. & Principle of Equation \\
\hline & de Procedure & & & 4. & Principle of Material Accuracy \\
\hline & & & & 5. & Principle of Balance \\
\hline & & & & 6. & Prohibition Principle detournament \\
\hline & & & & & de pouvoir \\
\hline & & & & 7. & Asas Larangan Willekeur \\
\hline
\end{tabular}

Table 2 Principles in General Principles of Decent Governance

Source: Https://Leip.Or.Id/Wp-Content/Uploads/2016/05/Penjelasan-Hukum-Asas-Asas-Umum-Pemerintahan-Yang-BaikHukum-Administrasi-Negara (Accessed On June9, 2020)

Diversity in the use of the term General Principles of Decent Government will actually be able to cause confusion in terms of meaning. However, the terms, General Principles of Decent Government AUPL, and General Principles of Decent Government AUPNB are actually intended as principles or principles that are used by the government as the basis for governance, namely within the scope of the executive body, where this is used as the basis used in carrying out affairs public affairs which are part of his authority. Meanwhile, the AUPN itself is intended as a general principle which should be obeyed by government administrators which incidentally covers three branches of power in Indonesia (executive, legislative, and judicative institutions), with the aim of building governance that is clean and free of Collusion of Corruption and Nepotism.

Philipus M. Hadjon, dkk., Pengantar Hukum Administrasi Indonesia (Introduction to the Indonesian Law), cetakan Kedua, Gadjah Mada University Press, Yogyakarta, 1993, hlm. 280

Indroharto, Usaha Memahami (...), Op. Cit., hlm. 307 


\section{Conclusion}

From the results of the discussion and analysis that have been presented, it can be concluded as follows:

- General Principles of Decent Governance, are translations of 'Algemene Beginselen van Behoorlijk Bestuur' (ABBB), a term in Dutch. In England, this principle is known as 'The Principal of Natural Justice' or 'The General Principles of Good Administration', while in France it is termed 'Les Principaux Generaux du Droit Coutumier Publique' and in Belgium it is called 'Algemene Rechtsbeginselen', and in Belgium Germany is called 'Allgemeine Grundsätze der Ordnungsgemäßen Verwaltung'.

- The diversity of the use of the term A, in Indonesia can be seen from the difference in the use of the term in various literatures and laws and regulations. There are at least four different terms, but are intended to have the same meaning as the A, namely the term General Principles of Decent Governance, General Principles of State Administration (AUPN), General Principles of Decent State Government (AUPNB) , The Principle of Organizing Local Government (APPD), Principles of Good Governance, Principle of Providing Public Services (APP), Principle of Organizing Policy and Management of the State Civil Apparatus.

\section{References}

i. Angger Sigit Pramukti, 2016, Pengawasan Hukum Terhadap Aparatur Sipil Negara, Pustaka Yustisia, Yogyakarta.

ii. Azhary, 2003, Negara Hukum (Suatu Studi Tentang Prinsi-Prinsip Dilihat Dari Segi Hukum Islam), Kencana, Jakarta.

iii. A.V.Dicey, 1959, An Introduction To Study Of Law Of The Constitution, Mac, Millan \& Co, London.

iv. Bagir Manan, 1994, Dasar-Dasar Konstitusional Peraturan Perundang-UndanganNasional, FH. Univ Andalas, Padang.

v. C.F.Strong, 1960, Modern Political Constitution, Sidgwick \& Jonson Ltd, London.

vi. George Sabine, 1995, A History of Political Theory, G.Harrap Co.Ltd, London.

vii. Hamza Baharuddin, 2012, Bunga Rampai Hukum Dalam Kontroversi Isu, PustakaRefleksi, Makassar.

viii. Handri Raharjo,2016,Sistem Hukum Indonesia,Pustaka Yustisia,Yogyakarta

ix. Hazairin, 1973, Demokrasi Pancasila, Tinta Mas, Jakarta.

x. H.W.R.Wade, 1971, Administrative Law, Oxford, London.

xi. Inu Kencana, 2005, Pengantar Ilmu Pemerintahan, Aditama, Bandung.

xii. J.B.J.M. Ten Berge, 1995, Bescherming Tegen Overheid, W.E.J.Tjeenk Willink, Zwolle.

xiii. Kumorotomo, 1999, Etika Administrasi Negara, Rajawali Press.

xiv. Makhfuds,2014,Hukum Administrasi Negara, Graha Ilmu,Yogyakarta

xv. Maria Farida Indrati, 2007, Ilmu Perundang-undangan, Kanisus, Yogyakarta.

xvi. Miftah Thoha, 1991, Beberapa Aspek Kebijakan Birokrasi, Mandala, Yogyakarta.

xvii. M.Nasrun, Krisis Peradilan, ELSAM, Jakarta.

xviii. M.Nata Saputra, 1988, Hukum Administrasi Negara, Rajawali, Jakarta.

xix. Mukmin Muhammad, 2017, Etika Administrasi Negara, Deepublish, Yogyakarta.

xx. Ni'matul Huda, 2005, Negara Hukum Demokrasi dan Judicial Review, UII Pres, Yogyakarta.

xxi. Nurul Qamar, 2018, Negara Hukum Atau Negara Kekuasaan (Rechtstaat Or Machtstaat), Cv. Social Politic Genius,Makassar

xxii. Padmo Wahjono, 1982, Konsep Yuridis Negara Hukum Republik Indonesia, Rajawali, Jakarta.

xxiii. Phlipus M. Hadjon, 1996, Kedaulatan Rakyat Negara Hukum dan Hak Asasi Manusia, Media Pratama, Jakarta.

xxiv. Ridwan HR, 2010, Hukum Administrasi Negara (Edisi Revisi), Raja Grafindo, Jakarta.

xxv. Ramdlon Naning, 1983, Gatra Ilmu Negara, Liberty, Yogyakarta.

xxvi. Sarjono Soekanto, 2014, Penelitian Hukum Normatif suatu Tinjauan Singkat, Raja Grafindo Persada, Jakarta.

xxvii. Sahya Anggara, 2012, Perbandingan Administrasi Negara, Pustaka Setia, Bandung.

xxviii. Said Sampara,La Ode Husen,2016,Metode Penelitian Hukum (edisi revisi), Kretakupa Print,Makassar

xxix. --------,2008, Pemerintah Yang Bersih Korelasinya Dengan Tata Pemerintahann Yang LAYAK, Jurnal Konstitusi PKK-FH Universitas Muslim Indonesia,Makassar, Vol 1 No 1 Oktober 2008

xxx. Sastra Djatmika, 1964, Hukum Kepegawaian di Indonesia, Djembatan, Jakarta.

xxxi. Sri Hartini, 2008, Hukum Kepegawaian di Indonesia, Grafika, Jakarta.

xxxii. Sri Hastuti Puspitasari, 2005, Aspek-aspek Perkembangan Kekuasaan Kehakiman di Indonesia, UII Press, Yogyakarta.

xxxiii. Sri Soemantri M, 1992, Bunga Rampai Hukum Tata Negara Indonesia, Alumni, Bandung.

xxxiv. SF.Marbun dan Moh.Mahfud MD, 1987, Pokok-pokok Hukum Administrasi Negara, Liberty, Yogyakarta.

xxxv. Soehino, 1980, Ilmu Negara, Liberty, Yogyakarta.

xxxvi. Sondang P.Siagian, 2001, Kerangka Dasar Ilmu Administrasi, Rineka Cipta, Jakarta.

xxxvii. Sukarno Aburaera et.al,2016,Filsafat Hukum Teori dan Praktek, Prenadamedia Group,Jakarta

xxxviii. Undang-Undang Negara Republik Indonesia Nomor 5 Tahun 1986 Tahun 1986 Tentang Peradilan Tata Usaha Negara

xxxix. Undang-Undang Republik Indonesia Nomor 5 Tahun 2014 Tentang Aparatur Sipil Negara

xl. Undang-Undang Republik Indonesia Nomor 28 Tahun 1999 tentang Penyelenggaraan Negara yang Bebas KKN

xli. Mukmin Muhammad,2019, General Principles of Good Governance in State Civil ApparatusLaw, http://www.internationaljournalcorner.com/index.php/ijird_ojs/article/view/137024, [accessed Dec 062018 ]. 
xlii. Mukmin Muhammad,2019, General Principles of Good Governance (ALGEMENE BEGINSELEN VAN BEHOORLIJK BESTUUR) In State Civil Apparatus Law (A study of the general principles of good governance in law number 5 of 2014 on State Civil Apparatus. ),IJISRT Vol 4, issue 1,January 2019,https://ijisrt.com/general-principles-of-goodgovernance-algemene-beginselen-van-behoorlijk-bestuur-in-state-civil-apparatus-law-a-study-of-the-generalprinciples-of-good-governance-in-law-number-5-of-2014-on-state, [accessed on 18 January 2019]

xliii. MukminMuhammad,2018,Independensi,Yudisial,Sebagai,Pilar,Dari,Suatu,Negara,Hukum, https://merajajournal.merajamedia.com/index.php/mrj/article/view/7 [accessed Dec 052018 ].

xliv. AlgemeneeneBeginselen,https://www.denederlandsegrondwet.nl/id/vi42dj6ad7r1/algemeene_beginselen,De Nederlanse Grondwet,[accessed on February 06 2019]

xlv. Algemene beginselen van behoorlijk bestuur, https://www.jouwadvocaat.nl/pagina/algemene-beginselen-vanbehoorlijk-bestuur?type=101, Overzicht van advocaten, Nederland, [accessed on 1 January 2019] 